DOI: http://dx.doi.org/10.24093/awejtls/vol4no1.2

\title{
“Knowledge comes, but wisdom lingers...": A Genealogical Reading of Tennyson's Locksley Hall
}

\author{
Fatimah A. Alotaibi \\ College of Languages and Translation \\ Imam Mohammad bin Saud Islamic University (IMSIU) \\ Riyadh, Kingdom of Saudi Arabia
}

\begin{abstract}
This paper analyzed various themes and stylistic features of Lord Tennyson's poem, 'Locksley Hall.' The main themes that were examined include pessimism versus optimism, love and romance, future. Two stylistic features, namely monologue and the dramatic placement of trochaic rhythmic units, were examined. The analysis section provided a comprehensive analysis of these elements as they are depicted in the poem. The theoretical framework of this research was anti-historicism, as particularized in Foucault's genealogy. The discussion section placed these elements in the context of the theory of anti-historicism. The findings of this research indicated that this poem depicted the elements of the concept of the "history of the present" of the Victoria era.
\end{abstract}

Key words: Anti historicism, Friedrich Nietzsche, Genealogy, Locksley Hall, Lord Alfred Tennyson, Martin Heidegger, Michel Foucault, Victorian poetry

Cites as: Alotaibi, F. A. (2020). "Knowledge comes, but wisdom lingers...": A Genealogical Reading of Tennyson's Locksley Hall. Arab World English Journal for Translation \& Literary Studies4 (1)14- 23. DOI: http://dx.doi.org/10.24093/awejtls/vol4no1.2 